\title{
Spirituality in Social Work with Respect to the Helping Person's Education and Skills Tereza Cimrmannová
}

\section{Introduction}

At faculties of theology and in practice, theologians and ordained ministers cooperate with experts from other helping professions. This paper will focus on the dialogue between theology and social work. Despite many partial differences, these two disciplines have much in common, especially the view of the human being as a unity constituted of biological, psychological, social and spiritual aspects, whereby in social work these dimensions are perceived in the context of needs and commissions, depending on the various conceptions of social work. ${ }^{1}$ Another point of interception of the two disciplines, especially of pastoral and social work, is the support given to a freely acting human person, i.e., a subject. ${ }^{2}$ The space defined in this way places high demands on the helpers' expertise and sensitivity, especially of those who are anchored in a particular confession. In practice, it holds that without the necessary communication skills and interiorised limits one can do more harm than good.

It cannot be denied that spirituality significantly influences quality of life and coping with stressful situations. Scientific evidence has been presented with respect to the positive influence of an interiorised religious faith as a variable giving direction to a coping strategy and providing emotional support in a situation of extreme burden. ${ }^{3}$ But can we work safely with spirituality at a time when its definition encompasses every form of transcendence? Furthermore, most users of social services and a substantial part of the personnel of secular and church organisations are not anchored in a church. It cannot be expected that, for example, all the workers of the Catholic Caritas will endorse the moral norms of the Catholic Church, which can give rise to dilemmas and conflicts. ${ }^{4}$ Thus, the broad possibilities of spiritual development can be stimulating for the users of services, and for social workers, but also for theologians and ordained ministers. The spiritual needs of clients not belonging to a religious denomination are still a challenge. In Czech practice the term used for insufficiently saturated spiritual need is spiritual poverty; Svatošová employs the concept of spiritual pain and places it in connection with a loss of meaning, a need for forgiveness, or a fear of the unknown or of being punished. ${ }^{5}$

1 This paper is based on the professional conception of social work according to Musil. Cf. Libor MUSIL, Různorodost pojetí, nejasná nabídka a kontrola výkonu „sociální práce“, Sociální práce / Sociálna práca 2/2008, p. 66.

2 This is not contested by the fact that some social workers, ordained ministers or pastoral workers do not respect this principle, whereby they deform the public image of their professions.

3 Cf. Kenneth PARGAMENT, The Psychology of Religion and Coping: Theory, Research, Practice, London: The Guilford Press, $1997, \mathrm{p} .180$. Cf. Petr KOLAŘÍK, Identita sociálních služeb poskytovaných katolickou církví, Sociální práce / Sociálna práca 4/2008, p. 79.

Cf. Marie SVATOŠOVÁ, Víme si rady s duchovními potřebami nemocných?, Praha: Grada, 2012, p. 64. 
Are social workers prepared for such a subtle topic with respect to their capacity, education, skills and personality setup? To what extent is the personal spirituality of the social worker professionally significant? Is it appropriate to bring it into conversations with clients? What if the client asks about the helper's worldview directly? This paper aims to briefly specify the answers to the above questions, point out some of the dilemmas and present several incentives for the dialogue of theology with social work. A partial goal is to contribute to the elimination of the myth of social work as a synonym for all-rounded social care for a neighbour in need. That conception does not accord with the practical possibilities of social work and does not correspond to its educational standards. Besides, social workers can automatically be regarded as experts in a whole spectrum of social problems. But the expert position of a social worker in specific spheres derives from the quality of his tertiary and lifelong education, according to the needs of practice. In the Czech situation, finding an educational space in which selected social workers would gain practical skills of dealing with spirituality is still an open question.

\section{The effort at dialogue between theology and social work}

A number of faculties of theology have stimulated the need to supplement the academic education of theologians with the practical dimension of a helping profession. The effort to mediate to students of theology, viz. to potential pastors, the skill of conducting interviews, crisis intervention or counselling skills must always be welcomed. For Czech pastoral practice still grapples with a certain level of uncertainty in these spheres and social work has a lot to offer here. ${ }^{6}$ Furthermore, the dialogue of theology with the helping professions is naturally rooted in the churches' charitable and diaconic mission, as described in a number of academic publications and ecclesial documents.?

In Czech theoretical understanding, the possibilities of theology's dialogue with social work have been grasped fairly recently, yet in a remarkable way. Opatrný thinks of social work as of a path to defending true dignity. In the context of a more complex analysis of social functioning, i.e., the uniqueness and needs of the individual human being and the community, while at the same time critically reflecting upon the real causes, it is possible to speak of social work as a sign of the times. ${ }^{8}$ The literature further accentuates the common ethical foundations of social and pastoral work. 'The normative foundations of social work are ethical principles and principles of human rights. The view of the human being is holistic, respecting the various dimensions of his existence, including the spiritual dimension.9 Some master's degree theses have also made interesting contributions to the dialogue of the two fields. Mossóczy in her text makes use of her experience with charitable work and illustrates her theoretical compilation on the subject with interviews with five directors of charities. Among other things, they give rise to a number of incentives concerning the relationship of parishes and charities ('The director of the charity is often very lonely. The priest seems not to know what he should do with him.'). ${ }^{10}$

So the dialogue of theology with social work is proceeding in a lively manner at the level of aca-

6 The Association of Hospital Chaplains has stimulated the eliminating of the blind spots of practical education, especially in the sphere of conducting interviews and crisis intervention by ordained ministers.

7 Cf., for example, Deus caritas est $30 \mathrm{~b}$ ).

8 Cf. Michal OPATRNÝ, Sociální práce a teologie. Inspirace a podněty sociální práce pro teologii, Praha: Vyšehrad, 2013, pp. 265-280.

9 Cf. René MILFAIT, Společné etické základy pastorační a sociální práce, in: Etika pro sociální práci, Ondřej FISCHER and René MILFAIT et al., Praha: Jabok, 2010, p. 148.

10 Cf. Martina MOSSÓCZY, Charita ČR, její poslání, činnost a vize v současné české společnosti (diploma thesis, thesis supervisor Tereza Cimrmannová), Praha: Husitská teologická fakulta Univerzity Karlovy v Praze, 2016, p. 83. 
demic work, although implementing scientific knowledge into practice can pose problems. Both theory and practice at times suffer from a certain educational deficiency on both sides of the coexisting fields, sometimes even with a lack of effort to know and respect the partner field in greater depth. It is really difficult to access the foundations of another field and the various conceptions of it if one is over-saturated by stimuli in one's own field. As a result, surprising errors easily occur in the work of scholars - fortunately rather at the level of theory or terminology. ${ }^{11}$ Interdisciplinary dialogue still thrives in tertiary education. The question is, however, whether we can make meaningful use of this space. Can demanding academic lectures be a suitable path to understanding theology for social workers, or are they a 'necessary evil' which makes the abyss between the two fields even broader? Of course, it can be a demographical problem (a temporary lack of students willing to perceive their subject in deeper contexts) and a pedagogical one. From a didactical point of view the present situation, where the majority of students studying at faculties of theology have no relationship to a confession or to Christianity, presents a real challenge.

\subsection{Several remarks on the identity of social work}

Social work, especially when it is studied at a theological faculty, can be erroneously understood by the public as a synonym for Christian love in the sense of agape or a human attitude without a claim to professional expertise. However, social work is a university discipline, having autonomous methods and ethical principles and places high demands on the graduates' professional and moral development. That is why a social worker is obliged to graduate from a higher professional school or from a university, unlike a caregiver, nurse or educator. ${ }^{12}$ And yet the question suggests itself regarding what exactly is a social worker and precisely what has been studied for years, when it is possible to help neighbours without an education. Relevant answers exist and this paper addresses them tangentially (section 3 ). ${ }^{13}$ But are social workers themselves able to reply to this question in a qualified way? How do they contribute to the renown of their profession? Can we as social work theorists dissuade a student from a master's thesis topic which is not directly connected with the intentions of the field? Or should we still accept the superabundance of canistherapy and euthanasia, whereby the choice of topic is justified by a single sentence? ${ }^{14}$

The abyss between the theory and practice in the helping professions is deepened by a mixture of the outer and inner misinterpretations described above, especially in social work. One of the topics, which is addressed only in theory, is spirituality. In the context of the cooperation of theology and social work, there is talk of the pastoral dimension of social work, i.e., of supporting the client in attaining personality development and an 'authentic increase in quality of life. ${ }^{15}$ Such aiming, without necessarily using the term 'pastoral dimension', is the focal point of social work, in which students of social work ought to develop continually. The added value of studying at theological faculties can then be precisely the ability to facilitate the client's spiritual and religious progress. This paper does not aim to evaluate to what extent we succeed in this. But the discourse

11 An example of a theological text erroneously conceiving social work as a profession in its own right is the otherwise excellent paper by David BOUMA, Několik poznámek k rizikům sociální práce duchovních, in Rizika sociální práce, ed. Martin SMUTEK, Friedrich W. SEIBEL and Zuzana TRUHLÁŘOVÁ, Hradec Králové: Gaudeamus, 2010, pp. 133-137.

12 None of these professions are less valuable or demanding. It is a matter of methods, tools and competencies.

13 The extensive discourse in professional periodicals on the education and identity of social workers shows that the field is developing dynamically.

14 For example, When I was studying social work I became particularly interested in canistherapy. Or, Euthanasia is still a burning problem in the social sphere. But the role of social workers in those two spheres is negligible in practice.

15 Cf. Ondřej FISCHER, Sociální práce může mít pastorační rozměr nejen v oblasti vztahu ke klientům, Sociální práce / Sociálna práca 4/2008, pp. 50-53. 
cited above and below suggests that the well-intended question of working with spirituality can in practice be much more complex that we would wish it to be.

\section{Spirituality and religiosity}

The term 'spirituality' is generally understood to signify an individual phenomenon having to do with personal transcendence and meaningfulness of life. Religiosity is a human being's personal relationship to religion, the Church, and its teaching. ${ }^{16}$ These definitions are in general accord with many other sources, in which these concepts are analysed in detail. A special emphasis is placed on spiritual searching as a creative process, also in traditional Christian spirituality. ${ }^{17}$ Spirituality is the prerequisite or talent of the human being to transcend beyond the tangible world and search for the meaning of existence in it. It is necessarily linked to inexact variables, such as love or secrecy, which is why it difficult to investigate it in a scientific way. Tomáš Halík questions the border between spirituality and religiosity when he writes '...faith (in the original biblical sense of the word) is not holding on to some specific views and "certainties", but the courage to enter the space of mystery.18

What form of spirituality approximates the needs of the contemporary human being? It is spirituality with an emphasis on searching and creation, not on adopting ready-made truths, for it is a spirituality renewing the harmony between body and mind, with neighbours and with the Sacred. ${ }^{19}$

\subsection{Spiritually sensitive and spiritually oriented social work}

In his texts Kaňák summarises the knowledge concerning social work which takes into account an individual's spiritual needs as an integral part of the quality of his life. He supplements the summary with his own research and recommendations for professional practice. Spiritually sensitive social work assumes the spiritual dimension of the service user, which it takes into account in the context of a bio-psycho-social-spiritual unity. A reflective approach is supported, but in practice this does not mean that social work explicitly works with spirituality. On the contrary, one of the goals of spiritually oriented social work is the active spiritual development of the individual. The spiritual dimension is perceived as a crucial dimension of the quality of life. But the realisation of spiritually oriented social work is conditioned by the helper's training in spiritual interventions. Only in such a context is it possible, for example, to pray with clients or for clients, to motivate them to meditation and to reading spiritual texts, or to work on issues of forgiveness. ${ }^{20}$

It needs to be stressed that both approaches are grounded in respect for the client's personal conviction and in the assumption that the spiritual dimension is to be brought into social work only in case the commission comes directly from it. Both approaches also start from the selfreflection of the worker's spirituality, already in the first preparatory phase. They also both support the search for appropriate spiritual activities with respect to reflective coping with life situations.

16 Cf. Michal STRİŽENEC, Súčasná psychológia náboženství, Bratislava: Iris, 2001, p. 39.

17 Cf., for example, Věra SUCHOMELOVÁ, Senioři a spiritualita, Praha: Návrat domů, 2016, pp. 63-70.

18 Cf. Tomáš HALÍK, Chci, abys byl, Praha: Lidové noviny, 2012, p. 19.

19 Cf. Vladimír SMÉKAL, Pozvání do psychologie osobnosti: člověk v zrcadle vědomí a jednání. Brno: Barrister a Principal, 2001 , p. 13.

20 Cf. Jan KAŇÁK, Postavení diskursu spirituality v sociální práci, Sociální práce / Sociálna práca 4/2015, pp. 30-46. 


\section{The social worker as an expert in the client's spirituality?}

We know that spirituality is connected with the client's quality of life and also with the quality of the provided interventions. We have a theory of spiritually sensitive and spiritually oriented social work. Here, however, we will focus on practice.

Perhaps everyone who has experienced professional practice across target groups and has had an opportunity to observe the everyday agenda of a social worker can make a preliminary estimate of the spheres in which there is no space for spiritually sensitive or spiritually oriented social work in the given conditions. A social worker in a hospital barely copes with basic communication, securing subsequent social services, or taking care of the necessary formalities with the bereaved family. A social worker of a department of social and legal protection of children is too busy to address such an intimate issue as the client's spiritual life. Other spheres of social work, into which the client has involuntarily found himself, leading to the feeling that there is more control than help, are also generally unsuitable.

Besides that, it is possible to imagine a whole number of spheres in which secular and even so-called consecrated spirituality becomes a natural topic of conversation. This is by far not limited to situations of grave illness and the sphere of palliative care, although these are most typical with respect to the intensity and strength of conversations on spiritual topics. It concerns also all situations of grave loss and crises, when overcoming an acute psychological state is followed by a long period of searching for God, a new meaning of life, and of hope. With some overstatement one can say that for a significant number of social workers confronting these questions is a 'daily bread' and that they, consciously or unconsciously, stimulate spiritual life. By their profession, like other workers in helping professions, they are so close to human suffering that it is enormously stressful for them as well. If they have been able to fend off indifference, these situations raise burning questions for them also, although they themselves are not going through a crisis situation. It is therefore not possible to say that social work does not bring along a spiritual content. But, in the given conditions, only a tiny fraction of social workers can systematically work with spirituality so that it is useful for the client. Let me now add several observations from workplaces where spiritually oriented social work is assumed. ${ }^{21}$

- An unnamed hospice is thought of as a place for a dignified ending of life - this is evinced by feedback and the gratitude of the bereaved. But the conversations about faith (or lack of it), pains, hope, and forgiveness are conducted by some nurses or caregivers - not professionally, but because the topics are humanly familiar to them and they can listen to them. The hospice's director realised that it is necessary to reinforce the personnel by someone for whom communication would be the priority of his work. A young psychologist did not prove suitable, for the patients felt that he does not have the necessary life experience and perhaps even cannot establish a secure relationship. The management called in an experienced pastor of a protestant church, who had served as a hospital and prison chaplain, which turned out to have been a good choice. The social worker is in contact with the patients but, unlike the everyday communication of the healthcare personnel, the relationship is not established in such a way that it would be possible to speak on more intimate topics. The content of the social worker's work is administration, not spirituality. That is why 'the social' was not even considered as someone competent with respect to the dying persons' spiritual life.

21 The examples are merely illustrative. They probably do not reflect the overall situation, but they do really occur in practice. 
- Another unnamed hospice. A trainee asks the hospice's director: 'Do you work with the patients' spiritual needs in any way?' 'Yes, a Catholic priest comes here on request. But it happens rarely, we do not have many religious patients here.' Question: 'And what if some of the non -religious patients need to speak about their life, perhaps about grievances and forgiveness ... or at the end of his life searches for its meaning or for the meaning of his pain?' Answer: 'As a long-term hospice director I tell you that pain has no meaning. We have no questions like that here. Let us go on. The social worker's role here consists in administration and basic communication with patients and their families.

- A large day-care facility for mentally handicapped adults. A competent person has been entrusted with spiritual questions including dying (here in the role of a special pedagogue, she is also a graduate of social work). But the clients' openness is impaired by a number of obstacles on the part of colleagues and the topic needs to be addressed in teamwork. The competent person acquires allies with difficulty and overcomes the barriers associated with a biased perception of spirituality.

- A Christian home for the elderly in a small town. The management perceives the need to communicate with clients on spiritual topics, and its attitude is favourable. But it was difficult even to find a social worker with the required education, much less a spiritual administrator. The situation is addressed by a crash activity by volunteers (reading from the Bible, prayer). The social worker has the capacity to cope well with accompanying in practical matters: expert counselling in matters related to financial benefits, accompanying to public institutions, obtaining health and other services, communication with families, and administration.

- Social work on the ground with a target group of persons suffering from a mental illness. Successfully applied case management, rigorously individualised approach, and qualified social work according to the educational standards takes place. But in practice there are so many practical issues to be addressed (medication, state authorities, accommodation, employment) that there is no time even to open up spiritual questions. If it exceptionally happens, the social worker does not feel competent to deal with the issue, which is why he merely thinks along with the client about the possibilities of spiritual life in the vicinity. However, that kind of commission is sporadic.

- A home with a special regime for persons with dementia. There is no systematic conception of dealing with spirituality. The possibility to ask for a priest is rarely used. The spiritual needs of clients, for example, questions about the meaning of life with a serious illness, are appeased intuitively. Communication derives from the helper's current spiritual frame of mind and feeling. Since the personnel situation is dismal, the competences of the individual employees become mixed up. The roles of a social worker and of a worker in social services are not distinguished. 'When it is necessary, even the caretaker changes sanitary pads.'

In such circumstances, should the social worker really be a prototype of an omnipotent professional, or even of a postmodern superhero? ${ }^{22}$ To summarise the responsibilities for which he is being prepared in the course of his study, the list will be at least as follows: defending the clients'

22 Cf. Martina BARÁKOVÁ, Michal KACZOR and Markéta ELICHOVÁ, Sociální pracovník jako archetyp postmoderního superhrdiny?, Sociální práce / Sociálna práca 5/2016, pp. 122-131. 
rights, theoretical and practical familiarity with the methods of social work, respect for the profession's ethical principles and the ability to orient oneself in grave dilemmas, high frustration tolerance, excellent communication skills and self-reflection, basic psychological and somatological knowledge, the ability to cope with so-called incongruous expectations of society, and generally also accepting a lack of financial or other appreciation. With some overstatement one can say that in this context the theological incentive that suggests itself is the topic of asceticism, sacrifice or martyrdom. And it seems that another demanding skill, viz. working with spirituality, will be a matter only for motivated, specially-gifted social workers. In other situations the clients will profit more from a recommendation of another suitable service, or of a colleague who is educated in matters of faith, hope and spiritual pain.

\section{Outline of a solution and incentives for educators}

Social work, especially in church-operated social services, takes the client's spiritual dimension into account. But if the social worker is not equipped with experience and does not have a practical familiarity with working safely with spirituality, he ought not to attempt to do it by trial and error. If he maps the client's spiritual needs as pressing, he can mention his professional incompetence and offer the opportunity to converse with a trustworthy colleague. In the practice of church organisations, it is normally a pastoral worker who is by his profession prepared to listen to spiritual pains. But sometimes it happens that the pastoral worker expects religious topics, and in their absence he may feel that it is not the sphere of his activity. It would be beneficial if the study of pastoral work focused in greater depth on the spiritual needs of persons without a religious confession and if pastoral workers graduated from their subject equipped with the skills of conducting interviews, accompanying, and facilitation. In this context, the art of listening is more valuable than academic knowledge of the highest quality. ${ }^{23}$

Outstanding inspiration for conducting spiritual conversations even with so-called non-religious clients is provided by the activity of hospital chaplains. ${ }^{24}$ Although in the Czech Republic this profession arose in significant 'labour pains', in many hospitals this deficient space in healthcare (the psychosocial and spiritual pain of patients and personnel) has already been treated. The Association of Hospital Chaplains, which provides patronage for this profession, offers a number of practically oriented courses for ordained ministers who are willing to engage in further education. Since a frequent spiritual pain is so-called belated regret, it is also possible to be inspired by the experience of counsellors for the bereaved..$^{25}$

Besides the pastoral worker, the client's spirituality is frequently easily accessed by the worker of direct care who repeatedly comes to see the client (patient) and has established a relationship with him. So in practice these topics are paradoxically opened up with workers in social services or attendants, and not with university educated social workers. A naturally established relationship is such a precious prerequisite of communication that it again raises the question whether it would not be appropriate to develop the ability to listen and to securely accompany the client in spiritual matters in selected direct care workers.

23 Unfortunately, not everyone who has taken a course in social and pastoral work, or in theology and social work, is an expert equipped to conduct spiritual conversations. Education in large groups, without adequate practice and supervision, provides only a basic orientation in the sphere.

24 Prison, police and army chaplains are also of irreplaceable significance.

25 Councillor for the Bereaved is a new profession within the National Vocation System. Late regret is often experienced by people who have accompanied someone close at the end of their life. It is to do with the feeling of guilt that they could have coped with the situation better. 
The discussion of spirituality calls to mind other pressing topics that have recently been addressed in social services. One of them was the controversial topic of relationships and the sexuality of mentally handicapped adults, especially within the social service of supported housing. Each organisation needs rules to regulate the existing situations and a competent worker who co-ordinates the topic. Well-functioning organisations have thus created methodological materials, so-called sexuality protocols, and the role of the trusted person in the field. This model can serve as inspiration for other subtle topics, among others spirituality.

If the model of spiritually sensitive and spiritually oriented social work developed in the Czech Republic, an emphasis on more directed, continuous self-development in tertiary education would certainly be beneficial. Especially, professional practice ought to focus on social work with specific goals, clear outputs, and in the presence of a mentor - the social worker. ${ }^{26}$ If, with respect to spiritually oriented social work, appropriate knowledge, methodological materials and a defined quota of necessary education is lacking, the topic can gradually be treated by academic research, and also by the empirical parts of master's theses.

Another demanding but suitable method of working with spirituality is hagiotherapy. ${ }^{27}$

\subsection{The issue of the helper's spirituality - selected recommendations}

Even in ethically dilemmatic situations the social worker should still be a professional. But that does not imply moral neutrality if the client's solution does not accord with his conscience. There is still the option of communicating his view, or of relegating the client to a colleague. However, one of the main principles of social work is a non-evaluating approach and support of the client's self-determination. It is therefore appropriate to emphasise that the communicated attitude is personal, deriving from a particular story, and not to fill the space allotted to the client with it very much. The central question in a situation when a client manifests interest in the helper's worldview is: How will the client benefit from the information?28

Beyond dilemmatic situations, the social worker declares his faith only if the client asks. If he regards faith as an overly personal question or feels that there is a risk of professional limits being violated, he is not obliged to answer. An exception is a situation when there is a danger of loss of contact with an especially vulnerable client. ${ }^{29}$

The mission and values declared by a church organisation are a suitable support for communication. Besides providing conceptual apparatus, they delineate the space in which the service is realised. Respect for them is assumed but adopting them cannot be required, whether by service users or from employees. A conversation with a worker who merely listens (and does not press or offer) can assure the client that he has chosen a suitable service.

Unrequested missionary activity in social services can have a strong discouraging effect. The client must not be used as an instrument of mission or proselytism. The diaconic mission consists in

26 As part of graduate practice at the Hussite Faculty of Theology, in the course Social and Charity Work, we strive for a more systematic practical education in social work. If the student requests to be supervised by a pastoral worker, he certainly has reasons for it and his request is granted. As part of their practice, students fulfil so-called expert events, i.e., various conferences or seminars according to their personal profile. Conducting practice, expert supervisions and professional self-development can be inspired by the quality of practical education at higher professional schools.

27 Cf. ( $)$ Prokop Remeš, Hagioterapie. Společnost pro hagioterapii a pastorační medicínu (online), at: www.hagioterapie.cz, updated 21st December 2016, retrieved 30th December 2016.

28 This formulation arose as a result of consultations with PhDr. Jarmila Rollová and Mgr. Helena Wernischová at the Evangelical Academy in Prague.

29 Cf. Jarmila ČIERNÁ and Jan MAMULA, Duchovní témata a krize, in: Krizová intervence, Daniela VODÁČKOVÁ, Praha: Portál, 2012, pp. 320-321. 
the helping, even without the Christian organisation's other interests. ${ }^{30}$

Conversations concerning God and the faith tend to have a strong emotional load. The helper ought to have sufficient temporal and energetic reserves to be able to cope with these emotions. If he is uncertain, he ought not to enter into spiritual topics.

Neither a formal theological education nor holding the function of spiritual administrator by obligation is a suitable prerequisite for conducting professional conversations concerning spiritual life. Intuitive dealing with the client's spiritual dimension also need not be safe with respect to the consequences of such a conversation. But by active listening the helper generally does not make anything worse.

\section{Conclusion}

The spiritual dimension of a human being in a difficult life situation is still an important area of social work. But, apparently, everyday practice is as yet not ready to proceed according to the model of spiritually oriented social work in accordance with its professional conception. Unqualified activity in the sphere of spirituality is not beneficial for the client. In the process of social work there is a threat of violating the safe limits, of emotional excessiveness and divergence from the commission, of the space being unnecessarily filled by the helper's story, of satisfying the helper's religious needs, and a risk of the loss of trust. Especially in church organisations with an authoritative atmosphere, there is the danger of abusing power in the name of personal faith. These risks can be eliminated by a proper education focused on conducting a respectful and supportive conversation, internalising the helper's ethical principles, working with boundaries, and supervision. Sufficient inspiration can be drawn from theories of social work and from practical theology, from the practice of experienced pastoral workers, hospital chaplains, and also from councillors for the bereaved. A rounded educational system is still an open challenge, especially for theological faculties and for non-profit organisations envisaging education in the helping professions. Spiritual topics ought not to be reduced to issues of a particular religious faith. Perhaps people who are not anchored in any church are the ones most in need in this sense, as they ask the spiritual questions in an all the more pressing way.

In practice it happens that a worker does not explicitly express his faith, but the client can feel it. In that way a spiritual space is naturally opened up and reinforces both parties in the helping process.

30 Cf. Michal OPATRNÝ, Služba potřebným - diakonie jako konstitutivní prvek praxe církve, in: Praktická teologie pro sociální pracovníky, Michael MARTINEK et al., Praha: Jabok, 2010, pp. 62-70. 


\title{
Spirituality in Social Work with Respect to the Helping Person's Education and Skills
}

\begin{abstract}
The spiritual dimension significantly affects the quality of life, which is beyond dispute today. The concept of spiritually sensitive and spiritually oriented social work has been elaborated well in theory. However, under what conditions are these concepts workable in practice? How significant is the social worker's personal spirituality in communication with the client? The text also presents the limits and risks, due to which many social workers in religious and other organisations are not or cannot be experts in clients' spiritual needs. This does not negate the significance of spirituality in social work, albeit it need not be explicit. Yet there are several possibilities of focusing on spirituality in the helping professions in a qualified way. The blind spot and challenge in the Czech practice is the spiritual needs of clients who do not belong to any religious denomination.
\end{abstract}

Key words: spirituality, social work, theology, education, skills, spiritual pain

\author{
Author contact \\ Dr. Tereza Cimrmannová \\ Charles University in Prague \\ Hussite Faculty of Theology, Department of Psychosocial Sciences and Ethics \\ Pacovská 350/4, 14021 Praha 4 \\ TerezaCimrmanova@email.cz
}

